
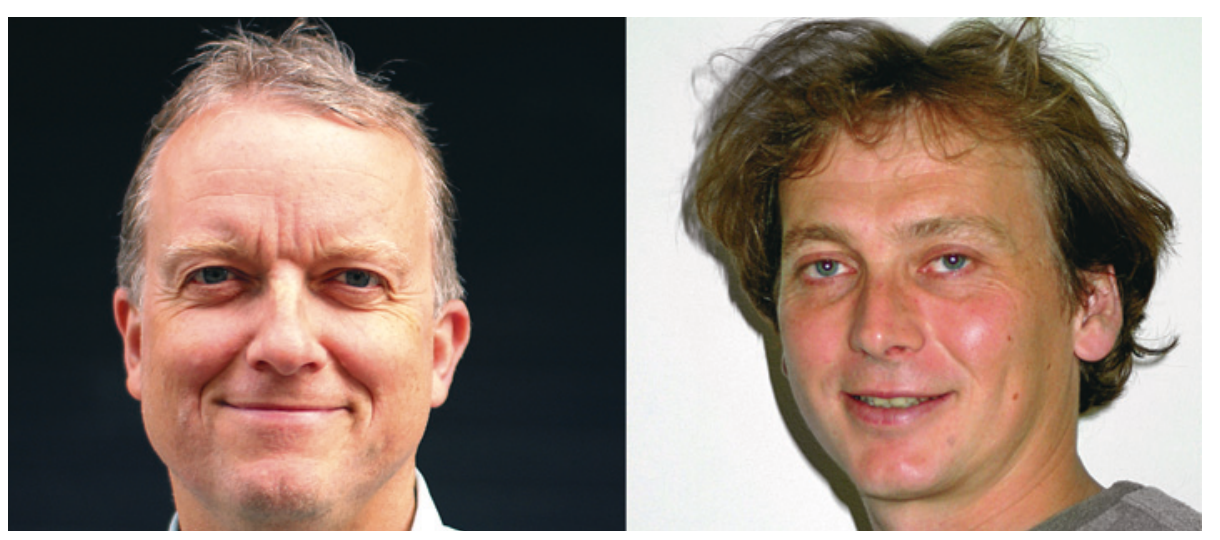

Ordforklaringer

Barnedødelighet: Årlig dør nesten åtte millioner barn før de har fylt fem år. Risikoen for å dø er høyest like etter fødselen. Nesten halvparten av dem som dør, dør i løpet av første levemåned. Sepsis, pneumoni og andre alvorlige bakterielle infeksjoner forårsaker minst en firedel av disse dødsfallene (1). Dette er tilstander som krever tidlig og oftest kostbar medisinsk behandling.

\title{
Litteratur
}

1. Black RE, Cousens S, Johnson HL et al. Global, regional, and national causes of child mortality in 2008: a systematic analysis. Lancet 2010; 375 : 1969-87.

Halvor Sommerfelt og Tor A. Strand. Foto privat

\section{Sink mot infeksjon hos barn i u-land}

Sinktilskudd er gunstig ved alvorlig bakteriell infeksjon hos spedbarn i India.

Sink er viktig for immunforsvaret, og daglig sinktilførsel kan redusere risikoen for diaré og pneumoni (1). Sinktilskudd til barn med diaré reduserer sykdomsvarighet og død (2). Sinktilskudd inngår derfor nå i WHOs anbefalinger ved behandling av diaré hos barn.

Sammen med forskere i New Delhi, India har norske forskere gjennomført et klinisk forsøk med 700 indiske barn i alderen 7-120 dager (3). Barna var innlagt i tre ulike sykehus i New Delhi med mistanke om alvorlig bakteriell infeksjon. De ble randomisert til å få 10 mg sink per dag eller placebo inntil utskrivning. Alle fikk standard sepsisbehandling.

Hovedmålet med studien var å måle effekten av sinktilskudd på risikoen for terapisvikt. Både inklusjonsdiagnosen og terapisvikt ble definert ut fra en rekke kliniske kriterier basert på WHOs retningslinjer. To barneleger avgjorde i fellesskap om et barn hadde terapisvikt. Studien var dobbeltblindet, så legene som avgjorde om barna hadde terapisvikt, hadde ikke kjennskap til om barna hadde fått sink eller placebo.

34 barn i sinkgruppen (10\%) hadde terapisvikt mot $55(17 \%)$ i placebogruppen, dvs. en reduksjon i forekomsten av terapisvikt på $40 \%$. Det var $43 \%$ færre dødsfall blant dem som fikk sink, men denne effekten var ikke statistisk signifikant, og også et sekundærutfall for studien. Det var få bivirkninger, og ingen av dem kunne tilskrives sinkbehandlingen.

- Denne studien viser at sink kan brukes til å behandle alvorlige bakterielle infeksjoner hos de yngste barna i fattige land, sier professor Tor A. Strand ved Senter for internasjonal helse ved Universitetet i Bergen, som var artikkelens sisteforfatter.

\section{Forskergruppen}

Studien var et av tre store kliniske forsøk $i$ et forskningssamarbeid finansiert $i$ hoved- sak av EU. Forskningssamarbeidet, som ble ledet av Tor A. Strand ved Senter for internasjonal helse (SIH) ved Universitetet i Bergen, hadde partnere ved to institusjoner i India, én i Nepal og institusjoner i Danmark og Frankrike. De tre kliniske forsøkene omfattet over 4000 barn og ble gjennomført i Nepal og India i perioden 2003-08.

Forskergruppen som studerer barnehelse og ernæring ved Senter for internasjonal helse, ledes av Halvor Sommerfelt. Gruppen er særlig opptatt av diaré, pneumoni, underernæring, hiv og andre sykdommer som fører til dårlig helse og død hos små barn i utviklingsland. Gruppen har i de senere år koordinert og gjennomført flere epidemiologiske studier og store kliniske forsøk i flere lavinntekts- og mellominntektsland og er nylig blitt utvidet med kompetanse innen mødrehelse. Strand og Sommerfelt har arbeidet med sink og infeksjoner i over 15 år. Noen av deres studier har vært avgjørende for Verdens helseorganisasjons anbefalinger om diarébehandling.

\section{Erlend Hem}

erlend.hem@medisin.uio.no

Tidsskriftet

\section{Litteratur}

1. Yakoob MY, Theodoratou E, Jabeen A et al. Preventive zinc supplementation in developing countries: impact on mortality and morbidity due to diarrhea, pneumonia and malaria. BMC Public Health 2011: 11 (suppl 3): S23.

2. Lukacik M, Thomas RL, Aranda JV. A meta-analysis of the effects of oral zinc in the treatment of acute and persistent diarrhea. Pediatrics 2008; 121: $326-36$

3. Bhatnagar S, Wadhwa N, Aneja S et al. Zinc as adjunct treatment in infants aged between 7 and 120 days with probable serious bacterial infection: a randomised, double-blind, placebo-controlled trial. Lancet 2012; 379: 2072-8.

\section{THE LANCET}

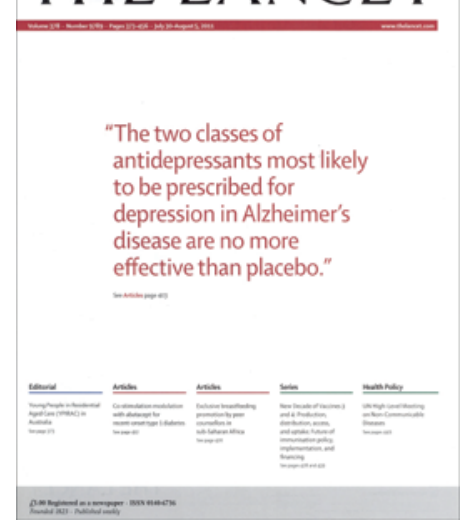

Artikkelen ble publisert 2.6. 2012 i The Lancet, som regnes som en av de «fem store» innen medisinsk publisering, ved siden av New England Journal of Medicine, JAMA, Annals of Internal Medicine og BMJ. (c) Lancet 2011, gjengitt med tillatelse fra Elsevier 